Article

\title{
Seeking Christian Theology in Modern Chinese Fiction: An Exercise for Sino-Christian Theology
}

\author{
David Jasper(D) \\ Department of Theology and Religious Studies, The University of Glasgow, Glasgow G12 8QQ, UK; \\ davidjasper124@gmail.com
}

Received: 13 June 2019; Accepted: 5 July 2019; Published: 9 July 2019

\begin{abstract}
The development of Christian theology in contemporary China can learn much from Chinese fiction beginning with $\mathrm{Lu}$ Xun and his dedication to writing for the spirit of the Chinese people. Increasingly, Chinese novelists have reflected the growth of spiritual life in the Chinese People's Republic in spite of the burden placed on the Christian church and religious believers.
\end{abstract}

Keywords: Sino-Christian theology; literature and theology; Lu Xun; comparative literature

This essay has its origins in many and various places. Its theological claims may seem to be extravagant. However, as the intelligent project of Christian theology seems to be faltering, perhaps terminally, in Western thought and imagination, the challenge is then being taken up in the more recent churches and universities of Southeastern Asia, and in the People's Republic of China in particular. The cultural and intellectual difficulties of a truly Sino-Christian theology extend far beyond the political and social limitations placed upon Christian thought and practice in China, for the difficulty of re-envisioning Christian theology, rooted as it is in the Bible and the categories of Greek philosophy, in the Confucian traditions of Chinese culture may be well-nigh insurmountable. This problem is illustrated in the very title of one important book on Sino-Christian theology, Pan-chiu Lai and Jason Lam's Sino-Christian Theology: A Theological Qua Cultural Movement in Contemporary China (Lai and Lam 2010), which asks the question as to whether we are concerned here with a theological or a cultural matter. Thus, for example, a review of Christian attention to the issue of Christology by Chinese theologians over the last hundred years or so will reveal that, almost inevitably it seems, Christ emerges as a Sage, a social reformer, lacking the dimension of transcendence that Greek philosophy readily supplies (Jasper 2018, p. 134). An example of this can be readily found in the writings of Wu Leichuan (1870-1944) and his influential book Christianity and Chinese Culture (1936), guided by proponents of the Social Gospel in Britain and the USA, which emphasizes religion as a force in social progress (Starr 2016, pp. 128-53). In the words of John Y. H. Yieh:

To show the traditionalists that Christianity did not conflict with Chinese culture, Wu Leichuan introduced Jesus as "Sheng tianzi" (holy son of heaven), the sage-king who performed the functions of king, prophet and priest. He also compared the Holy Spirit to the idea of ren (benevolence), the highest virtue in Confucianism. (Yieh 2008, p. 146)

Despite the revolutions of the twentieth century and the coming of Communism to China, traditional Confucian values continue to be upheld through such events as the government-sponsored Nishan Forum and at the Confucian Research Institute in Shandong and Qufu, the birthplace of Confucius. But within the categories of the Confucian culture that continues to characterize contemporary China in so many ways, Christian theology inevitably tends to become a program for social reform, rooted in the Nestorianism that has theologically always haunted Christianity in China since the first Nestorian 
Mission of 635 CE (Whyte 1988, pp. 33-37). ${ }^{1}$ These Nestorian Christians used Buddhist terminology in their translations from Syriac into Chinese until their expulsion under the Buddhist Empress Wu in $690 \mathrm{CE}$. But this, I wish to argue, is not the end of the story.

The study of literature and theology has recently benefited enormously from the work of William Franke and his book A Theology of Literature (2017). This is one of those small books that have considerable impact. Beginning with the literature of the Bible, Franke argues that literature provides that light of revelation that engenders a theology from within the literary traditions of human culture. As Franke puts it, the "ongoing interpretation of human experience is played out in exemplary fashion from the very beginning of the Bible" (Franke 2017, p. 13). I want now to develop this theological insight within the further and perhaps unlikely context of some recent Chinese novels. To do this, I enlist also the work of Zhang Longxi, professor of comparative literature and translation at the City University of Hong Kong, whose recent work seeks to expand the hitherto somewhat Eurocentric concept of "world literature" to embrace the rapidly developing literary tradition of China and Southeastern Asia in expanding conversations of cross-cultural understanding (Zhang 2015). Finally, I will use and adapt Maurice Blanchot's idea of l'espace litterraire-the space of literature. Within this space, and giving primacy to the literary moment, Blanchot has written of Franz Kafka, comparing him to the poet Hölderlin: "Kafka's passion is just as purely literary, but it is not always only literary. Salvation is an enormous preoccupation with him, all the stronger because it is hopeless, and all the more hopeless because it is totally uncompromising" (Blanchot 1982, p. 57). However, it is in the space of literature that this passion is engendered-a space without, itself, theological pretensions, but yet demanding a response from theology, a field in which the problems and anxieties of theology begin to be articulated or re-articulated. It is not the task of literature to articulate or construct any Christian theology, and the novelist is not a theologian by another name. But the novelist may explore anew the suffering, joyful narratives that prompt and demand the task of theology with its own creativities and purposes.

Some of the early impetus behind this thinking was inspired long ago by the "postliberal" theology of George A. Lindbeck in his book The Nature of Doctrine in the light of "a quarter century of growing dissatisfaction with the usual ways of thinking about those norms of communal belief and action which are generally spoken of as the doctrines or dogmas of churches" (Lindbeck 1984, p. 7). For Lindbeck and his "cultural-linguistic" approach to theology, the task is "intratextual" rather than "extratextual" - meaning, including religious meaning, lying immanent within the text, constituted by "the uses of a specific language" in the writing (Lindbeck 1984, p. 114).

For literary critics in the early 1980s, this would have come as no surprise after the projects of New Criticism and Structuralism, but Christian theology has never been as sensitive as literary criticism to cultural shifts in text and language, and hence the particular importance of Lindbeck's book (Culler 1975; Lentricchia 1980). Other, and perhaps more remote theological roots to this essay include, perhaps oddly, Thomas J. J. Altizer's radical theology and the death of God, precisely because it is found most deeply in a poetics and in literary texts from Dante to James Joyce. Altizer denies any theologically generated sense of the presence of God, and celebrates a profoundly apocalyptic vision that emerges also in the tenor of recent Chinese fiction. Although Altizer has no immediate political concerns, his vision of apocalyptic theology is shared also in the liberation theology of Gustavo Gutiérrez, with its references also to Marxist theory and his utopian hope for this world (Altizer 2012; Gutiérrez 1996, pp. 184-235). Finally, I am led by the French thinker Jean-Luc Marion to reflect upon the idea of the "saturated phenomenon" (of which Christ himself is the primary example) as that in which "intuition passes beyond the concept" - a concept that is at once essentially simple and at the same time profoundly ungraspable (Marion 2002, p. 199). This quality I also find, disturbingly, in the modern and contemporary Chinese fiction to which I now turn.

1 The first records of Christianity in China in the seventh century link the Nestorian city of Antioch, via the Silk Road, with the Chinese city of Chang'an. See further, Bob Whyte, Unfinished Encounter: China and Christianity (London: Fount, 1988), pp. 33-37. 
In his celebrated novel Silence, the Christian Japanese novelist Shūsaku Endō confronts us with a complex theological mystery in the silence of God in the context of the seventeenth century persecutions of Christians in Japan (Endō 1969). In modern China, the short story writer and essayist Lu Xun (1881-1936), who set out as a young man, so he tells us, to save the soul of his people through literature, confronts us even further with no God in an ancient Chinese culture that in the early twentieth century was struggling to move from ancient cultural complacencies in the late Qing dynasty into the new world of the Republic that began to emerge after 1911. The Western reader, reading in translation more often than not, quickly discovers that it is extremely hard to find a foothold in Lu Xun's stories. It is partly that their Chinese language, full of puns, odd metaphors, and repetitions, is so hard to translate into English, but far more than that, they seem to embrace a world that is entirely self-enclosed, shutting out all connections and external references.

We might compare the superficially similar conclusions of Lu Xun's novella "The Real Story of Ah-Q" $(1921)^{2}$ with the ending of the German writer Patrick Süskind's celebrated novel Perfume (1985). Süskind's conclusion plays with macabre, gothic horror on the imagery of the Christian Eucharist-a human body dismembered and utterly consumed by the crowd, ending in the provocative, shocking final sentence: "For the first time they had done something out of Love" (Süskind 1987, p. 263). "Ah-Q" also ends with the execution of the central character. These are the final words of the story:

Public opinion in Weizhuang was undivided: of course Ah-Q was a villain-he wouldn't have been shot otherwise. The verdict in town was more ambivalent: death by a firing-squad, the majority of them felt, wasn't a patch on decapitation. And the condemned had been a miserable specimen. In that whole extended tour around the streets, he hadn't managed to choke out a single line of opera; they had followed him for nothing. (Lu 2009, p. 123)

"Public opinion", then, can hide behind the final decision of the authority of the state: Ah-Q is guilty, and within the protection of that assurance, manifold, amoral, and utterly self-centered positions are available. Ah-Q is fair game. Even Lu Xun's narrator partakes of all such relativities, as his translator Julia Lovell has remarked: "our condescending narrator, we realize, is a thoroughly compromised man who slips between the various worlds he parodies" (Lu 2009, p. xxiii). And even $\mathrm{Lu}$ Xun himself refused to be pinned down as regards his story, commenting that "I wrote The Real Story with the intention of exposing the weakness of my fellow citizens-I did not specify whether or not I myself was included therein" (Liu 1995, p. 70).

At the same time, this troubling narrative opens up a space that is immune from all controlling spheres of power, be they political or theological. This space might, however, be illumined by a definition of "spirituality" as offered by Michel Foucault, whose last lectures, we should recall, explored exercises of power and the place of "truth acts" - that is, the place of individuals within procedures of truth-telling in relation to power and its absolutization. In some of his final words, Foucault explores such "truth acts" in early Christian writings and practices of spiritual direction (Foucault 2012). Foucault's claim that "there can be no truth without a conversion or a transformation of the subject" has been applied by Gloria Davies to the spaces of Lu Xun's fictions, their exposures and their possibilities (Foucault 2012, p. 232). A reader who is familiar with the literature of the gospels might hear echoes of the parables of Jesus (though surely not deliberate) in a brief fragment of a story written by Lu Xun in July 1920 entitled "A Minor Incident".

The narrator in this story-is it Lu Xun himself?-is clearly well-to-do, a citizen who has lived in Beijing for six years after the revolutionary upheavals of 1911 that brought an end to the Qing Dynasty, and is unimpressed by great national events except insofar as they induce in him a feeling of depression and contempt for his fellow citizens. But he is jolted by a small incident of a kind that is by no means unusual in Beijing or any other great city-a little street accident involving the rickshaw in which he is

2 Even the title of this novella defies any simple translation, playing with the idea of the real/true story-and somehow edged beyond the notion of "truth". 
travelling which inadvertently knocks an elderly, poor woman down. It is not the rickshaw runner's fault, for he swerved to avoid the old woman, but her clothes had caught in his rickshaw. The old woman is lying on the ground, probably not seriously hurt, and the narrator feels only irritation as his runner who, by staying to help the old woman, risks getting himself into trouble.

The rickshaw runner helps the old woman to her feet, even helping her towards a nearby police station, at great risk to himself as he may well be accused of knocking her over. The narrator is cross, perhaps afraid, but then is overcome by a paralysis that is both physical and mental. "It seemed to bear down on me, pressing out the petty selfishness concealed beneath my fur coat" (Lu 2009, p. 54). He walks towards a policeman, hands him some coins and walks away, a series of questions forming in his mind.

As I walked along, I was thinking-almost afraid I would turn my thoughts on myself. None of it had anything to do with me; so what had I meant by that handful of coins? Was it a reward? Did I have the right to pass such judgement? I could not answer my own questions. (Lu 2009, p. 54)

To the reader who is familiar with the Bible, there are almost inevitable echoes of the parable of the Good Samaritan (Luke 10:30-7), but as if told by the lawyer who asked Jesus the question, "who is my neighbor?". But it is the questions that cannot be answered and their uncomfortable spaces that might move us forward, and in them may be found the Lu Xun who is the "self-appointed literary physician of China's spiritual ills" (Lu 2009, p. xvii).

While he was still a student in Tokyo in 1907, Lu Xun, together with his brother Zhou Zuoren and some other students, founded a new journal of which the purpose was the revival of the classics of Chinese literature. Its title, "which was derived from the idea of creating 'new life'", ${ }^{3}$ was Vita Nova, but it failed even before its first edition was produced and only forty-one copies were sold (Lu 2017, p. 21). However, it served to emphasize the continuing link between modern Chinese literature and the Chinese Classics, to which I will return later on. Such connections are certainly apparent in the novels of Yu Hua (1960-), examples of what has become known as "scar literature" written in the aftermath of the period of Mao Zedong and the Cultural Revolution of 1966-1976. Yu Hua's best-known work, the novel To Live (1993), seems clearly to be written within the ancient Daoist tradition of submissiveness to fate and the inevitable. The precise nature of the central term of this tradition, Wu wei, is extremely difficult to capture in English, but it is a key term in the writings of Chuang Tzu who is perhaps the most spiritual of the classic Chinese philosophers. Literally it means "doing nothing" but it is actually more positive than that, suggesting more "not doing anything against the flow" (Chuang Tzu 2010, p. xvi). The Trappist monk Thomas Merton was moved to write an extended meditation on the Daoist tradition in his book The Way of Chuang Tzu (1965) in which he is quite clear that his work is the very opposite of any attempt to "find" Christianity in the Chinese tradition.

This book is not intended to prove anything or to convince anyone of anything that he does not want to hear about in the first place. In other words, it is not a new apologetic subtlety ... in which Christian rabbits will suddenly appear by magic out of a Taoist hat. (Merton 1999, p. 10)

And in the same spirit, I return to Yu Hua's To Live. An extraordinary Chinese film of this novel, in which Yu Hua was involved, remains banned in China, though available in the West. To Live follows the life of Fugui from a carefree and prosperous youth to an impoverished, patient old age. The final scene in the book is of Fugui ploughing with his old ox, an image of utter resignation-or perhaps something like $W u$ wei. 
The old man and his ox gradually got farther away, but from far off I could still hear the echo of the old man's hoarse and moving voice. It floated through the open night like the wind. The old man sang:

In my younger days I wandered amuck,

At middle age I wanted to stash everything in a trunk,

And now that I'm old I've become a monk. (Yu 2003, p. 235)

Yu Hua himself has expressed most precisely the heart of his fictional character.

After going through much pain and hardship, Fugui is inextricably tied to the experience of suffering. So there is really no place for ideas like 'resistance' in Fugui's mind-he lives simply to live. In this world I have never met anyone who has as much respect for life as Fugui. (Yu 2003, p. 244)

Yu Hua writes within the literary tradition of Lu Xun. Both writers began their careers within the field of medicine, in Yu Hua's case as a dentist. The uncompromising violence of his novels elicited the remark from his fellow writer Mo Yan: "I've heard that [Yu Hua] was a dentist for five years. I can't imagine what kind of brutal tortures patients endured under his cruel steel pliers" (Yu 2003, p. 239).

Even in the English translation one senses the linguistic experimentation and the radical, often painful, dissection of the soul of the Chinese people in novels like To Live or Chronicle of a Blood Merchant (1996; Yu 2004), each a novel of its time and place and yet each is disturbingly mythic and universal. They are immersed in a culture with philosophical, socio-cultural, and religious roots that are deeply Chinese, and also illustrate a more recent history that is still remote and almost unknown to most Western readers. Nevertheless, they speak with a powerful and urgent voice that opens up spaces for questions that resonate within universal religious traditions and prompt conversations across many barriers of faith and culture.

The fictional world of the novelist Yan Lianke is far from that of Yu Hua. His satirical novel Serve the People! is set in 1967, the second year of Mao Zedong's Cultural Revolution. Although the author is now Professor of Creative Writing at Renmin University of China in Beijing at the very heart of the Chinese political and cultural establishment, the novel remains banned by the Chinese government. The South China Post quoted the words of the propaganda department: "This novella slanders Mao Zedong, the army, and is overflowing with sex. Do not distribute, pass around, comment on, excerpt from or report on it" (Yan 2007, p. ii). Such is the paradox of China and the vitality of literature. Serve the People! is written very much in the style of the Czech writer Jaroslav Hašek's The Good Soldier Švejk and His Fortunes in the World War (1921) and begs comparison with the literature of Rabelais in its deliberate and satirical excesses. But Yan Lianke, of humble birth in rural Henan Province in China, speaks for those who have no voice, who are forgotten and trampled upon. Of his own writing, he has suggested:

Passion and anger are the driving force of my novels. Writers should pay attention to the emotional lives of the masses, births, deaths, and intolerable humiliation, the desperate situations of their existences. They are the majority but our literature happens to have abandoned them. (Yan 2007, p. iii) ${ }^{4}$

The relentless, satirical tone of Serve the People! allows the reader little resting place, the narrative endlessly disorientating and disrupting. The central character, the soldier Wu Dawang, is a humble sergeant of the Catering Squad, who is seduced by his military commander's young wife, Liu Lian, prompting an illicit erotic game between the two of them that involves smashing or destroying the

4 Yan Lianke, Serve the People! Quoted in the Preface. 
"sacred" symbols of the Revolution—statues of Mao, copies of the Little Red Book, epigrams of the Great Helmsman.

Yan Lianke sets out to be deliberately iconoclastic. Yet, oddly, the radical nature of the narrative again provokes literary reminiscences of the great narrative parables of St. Luke's Gospel with their stretched language, their surrealism, and their refusal to allow conclusion, uncomfortably to provoke thought. In its exposure of the Cultural Revolution, one might almost say of Yan Lianke's novel what Sallie McFague once wrote of the parable of the Prodigal Son:

One could paraphrase this parable in the theological assertion "God's love knows no bounds," but to do that would be to miss what the parable can do for our insight into such love. For what counts here is not extricating an abstract concept but precisely the opposite, delving into the details of the story itself, letting the metaphor do its job of revealing the new setting for ordinary life. It is the play of the radical images that does the job. (McFague 1975, p. 15)

Serve the People! is uncomfortable and unsettling even while it is being very funny, a narrative always refusing assertion and abstraction. Yan Lianke opens the book with a comment on the nature of the novel.

The novel is the only place for a great many of life's truths. Because it is only in fiction that certain facts can be held up to light.

The novel it is, then, for this particular truth.

The story I'm about to tell you, you see, bears some resemblance to real characters and events.

Or, if I may put it this way: life has imitated art. (Yan 2007, p. 1)

In the liveliness of the fiction we move beyond all definitions of theology or dogma, whether religious or political, its disruptions always a provocation to further thought and reflection upon truth.

It was in a seminar held in Renmin University of China in Beijing that I first met Yan Lianke. Present also was a woman novelist who is still in the early years of her career as a writer-Sheng Keyi, though now she writes in North America. Her most recent novel, Death Fugue (2014), has apocalyptic overtones as well as echoes of Paul Celan, but it is her first novel, Northern Girls: Life Goes On (2004) with which I am concerned here. Like Yu Hua, Sheng Keyi is rooted in traditional Chinese culture and, it might be said, spirituality, though her concerns are relentlessly contemporary. Northern Girls follows the life of Qian Xiaohong, a young girl from rural Hunan province, as she makes her way in the world of the modern Chinese city. In her Afterword to the novel, Sheng Keyi writes:

Qian Xiaohong is a familiar figure to me. She is typical of the people from my home village. When I started her story, I planned simply to write about the village, but once I began, I felt the place to be too restrictive for such a character. I wanted to toss her out into the wider world and see what she was destined to experience. Through the eyes of Qian Xiaohong and her companions-as well as the testimony of their bodies-we feel the cruel realities of the times and the difficulty of surviving. (Sheng 2015, p. 319)

Sheng Keyi's concerns are determinedly issues in contemporary China: urbanization, social dislocation, gender, and the place of women in what is still a profoundly patriarchal society. However, to readers who are familiar with the Bible, her narratives once again sound familiar echoes (perhaps unknown to the author herself)-in Northern Girls of the Prodigal Son-though here there is no return and no forgiveness for Qian Xiaohong-some of the women in the gospels, the decay of society in the prophetic tradition of the Hebrew Bible. And also, as with Fugui in To Live, but without his song and through gritted teeth, there is something of that ancient Daoist quality of resignation, though now with a deeper note of fatalism. Yet still Qian Xiaohong does survive despite her marginalization in Chinese society. The novel ends with the girl vanishing into the life of the city. 
Gritting her teeth, she bent her head and ... she stood. She trudged out of the ring of feet surrounding her and pushed her way down from the pedestrian bridge.

Then she faded into the crowds on the street. (Sheng 2015, p. 318)

We have heard a few fictional voices from the China of the tumultuous twentieth century and now the twenty-first century also. They are not the voices of the great and the powerful but almost always the voices of people from the bottom rungs of modern Chinese society. Beginning with the unstable, satirical narratives of $\mathrm{Lu}$ Xun, all of them echo something of the spirituality of ancient China that has never quite been crushed by the communist revolution, preserved, almost unconsciously at times, in the urge for self-expression found in writers and novelists who are only now beginning to be read and heard in the self-obsessed countries of Europe and North America. Even though he won the Nobel Prize for literature in 2000, by which time he was writing in exile in France, Gao Xingjian is still little read in the West. His great novel Soul Mountain (Lingshan) (1990, first published in Taiwan; Gao 2000) searches, like Lu Xun before had done, the "soul" of the Chinese people in a nonconformity that reaches deep into the literature and spirituality of what Karl Jaspers has dubbed the Axial Age of ancient wisdom in the almost contemporary Chinese Classics and the Hebrew Bible (Ziolkowski 2014, pp. 129-50). ${ }^{5}$ Only now, in the work of scholars of comparative literature like Zhang Longxi, are we beginning to explore a poetics of world literature, at the heart of which lie profound religious questions concerning creation and creativity (Jasper 2018, pp. 121-23).

Modern Chinese literature is still barely on the curriculum of comparative literary studies. Zhang Longxi points out that the standard textbook Norton Anthology of World Literature more or less ignored China until the "expanded" edition of 1995 (Zhang 2015, p. 174). The literature that I have been reviewing, however, carries disturbing echoes sounding from a non-Christian context of the preoccupations of liberation theology as it has welled up from South America in the writings of Gustavo Gutiérrez and others. In situations of oppression and the silencing of the majority, they share a sense of the need to embrace the complexity of the world and avoid in both theology and literature equally the dangerous simplifications of populism, not least religious populism (Gutiérrez 1996, p. 107). Oddly. they share a sense of what Gutiérrez, as a Christian priest, finds in prayer, that is, a need in human life ground down by utilitarian necessity for time that is "wasted", a free time to celebrate the gratuitousness of created being, though sometimes even this must be through gritted teeth (Gutiérrez 1996, p. 289). Then writers like Sheng Keyi, Yan Lianke, and Yu Hua share with liberation theologians (with whom they might seem to have so little in common) a sense of the nature of that poverty in society that may be profoundly material but is eventually something much more than that. As Gutiérrez expresses it:

Social classes, nations and entire continents are becoming aware of their poverty, and when they see its root causes, they rebel against it. We are facing a collective poverty which creates bonds of solidarity among those who suffer it and leads them to organize to struggle against this situation and against those who benefit from it. (Gutiérrez 1996, p. 293)

Writers like Gao Xingjian and Yan Lianke who are still silenced in the People's Republic of China write yet in expressions of the spirit that lives despite repression and coercion. Their literature offers hope and a space for a creative theology —and with that we begin to return to where we began our discussion, in the "cultural-linguistic alternative" of George Lindbeck's Nature of Doctrine. Lindbeck's description of this in his examination of religion and experience is, in his own term, "pretheological" (Lindbeck 1984, pp. 30-45). This is explored in terms of story and narrative-the materials of the novelist's craft. In Lindbeck's words:

5 Karl Jaspers dates what he calls the Axial Age (die Achsenzeit) as between about 800 and 200 BCE, describing it as a period of unprecedented human creativity across different cultures which had, seemingly, little contact with one another. It was the age of the great prophets of the Hebrew Bible and well as Confucius and Laozi in China. 
A comprehensive scheme or story used to structure all dimensions of existence is not primarily a set of propositions to be believed, but is rather the medium in which one moves, a set of skills that one employs in living one's life. Its vocabulary of symbols and its syntax may be used for many purposes, only one of which is the formulation of statements about reality. Thus while a religion's truth claims are often of the utmost importance to it (as in the case of Christianity), it is, nevertheless, the conceptual vocabulary and the syntax or inner logic which determines the kind of truth claims that religion can make. The cognitive aspect, while often important, is not primary. (Lindbeck 1984, p. 35)

It is within this lived medium of experience that we may encounter what the Roman Catholic philosopher and phenomenologist Jean-Luc Marion calls the "saturated phenomenon" within the "given" of being, well described by Robyn Horner, the English translator of Marion's book In Excess: Studies of Saturated Phenomena in this way: "givenness as the sole horizon of phenomena, and the possibility of phenomena that saturate intuition to such an extent that all horizons are shattered" (Marion 2002, p. ix).

Such a possibility describes well the disturbance and sometimes shock that is felt (rather than cognitively constructed), even in translation, in the fiction of Lu Xun, Yan Lianke, and the other Chinese writers we have visited, earning some of them the wrath of the political censor, and all of them claim to be speaking the nation's conscience, recovering its "spirit". In what sense, therefore, and in conclusion, should the pursuit of a Sino-Christian theology be alert to the "secular" literature of contemporary China, rooted, even in its sense of modernity, in the deep cultural roots of Chinese society and its literary history? Is it that, once the profound philosophical (and spiritual) differences between Christian theology in western culture, so deeply grounded in the Bible and ancient Greek philosophy, and Chinese culture founded upon ancient Daoism and texts of Confucius have been acknowledged, then also their profound connections should also and equally be recognized (Geng 2016)? In a remarkable essay entitled "The Contemporary Significance of Theological Ethics", Yang Huilin, a distinguished professor of comparative literature at Renmin University of China in Beijing, compares the experiences of Auschwitz and the Cultural Revolution (through which he himself lived). Yang writes that

[... ] in at least two dimensions they link together the experiences of horror and survival in both East and West, which entailed (1) the fantasies and fanaticism of collective unconsciousness, and the uncontrollability of the two combined; and (2) the frailty of humankind's existing values, order, and standards. (Yang 2014, p. 61)

Bearing in mind such common experiences and the capacity, in spite of all differences, for the voice of literature to be heard and felt across all cultural divides in novels which I have here touched upon, and they are but a very small selection taken from a rapidly growing library of contemporary Chinese literature being now translated, we return finally to the project of Sino-Christian theology. We might presume, however, in the context of the present discussion, to suggest the possibility also of a Sino-Christian theology of literature, a theology that is, in a sense, implicit in works of literature that would not own to be either "religious" or, even less, Christian.

The term Sino-Christian theology was first used during the 1980s, largely among the so-called "cultural Christians", unbaptized but sympathetic to the Christian faith, who were to be found among the Chinese intellectuals in the universities of the People's Republic of China. Thus, and distinct from other Christian expressions in China today, Sino-Christian theology is primarily an academic exercise addressing the profound philosophical differences between cultures and the task of Christian theology to negotiate them intellectually (Yang 2010, pp. 101-22). But it cannot only be an intellectual enterprise. For as Chloë Starr has emphasized at the beginning of her recent book Chinese Theology: Text and Context, "literary form and theological content are indivisible" (Starr 2016, p. 3). Thus, as we embark upon the theological project, the Chinese literary forms, within which theology finally has its being, need to be acknowledged and experienced. For example, Starr notes how Chinese texts, both ancient 
and modern, tend to be "relational" — and thus Chinese theology may be also. Starr enlarges upon her observation:

A common heritage in the Chinese classics and a reading pattern that proceeds via a series of implicit associations in the mind of the reader create a more participative and open-ended way of reading and of engaging with theology. It is a theology that does not just draw from the church and reflect back church thinking, but asks readers to comment on and add to the debates as the texts are written and circulated. (Starr 2008, p. 3)

When I first read these words, I realized immediately that they illuminated my struggle to read fictional writers like Lu Xun as much as directing me towards a way of engaging with theology. In the elusive, often implicit moves of a fiction that was "saturated" with the phenomenal life of post-1911 China, new and passionate spaces for "doing theology" were opened up, spaces that did not reduce the necessary intellectual challenges but suggested at the same time new ways of thinking and dialogue that offered previously unrecognized opportunities of discussion. Are we perhaps close here to the spiritual vocation that $\mathrm{Lu}$ Xun saw as his as a writer for his people in their lassitude in the face of violence and suffering, writing in the Preface to his first collection of short stories: "The first task was to change their spirit; and literature and the arts, I decided at the time, were the best means to this end" (Lu 2009, p. xvii)?

Literature, in its task of liberation, and theology, finally, cannot be separated.

Funding: This research received no external funding.

Conflicts of Interest: The author declares no conflict of interest.

\section{References}

Altizer, Thomas J. J. 2012. The Apocalyptic Trinity. New York: Palgrave Macmillan.

Blanchot, Maurice. 1982. The Space of Literature. Translated by Ann Smock. Lincoln: University of Nebraska Press. Chuang Tzu. 2010. The Inner Chapters. Translated by Solala Towler. London: Watkins Publishing.

Culler, Jonathan. 1975. Structuralist Poetics: Structuralism, Linguistics and the Study of Literature. London: Routledge and Kegan Paul.

Endō, Shūsaku. 1969. Silence. Translated by William Johnston. New York: Taplinger.

Foucault, Michel. 2012. On the Government of the Living. Edited by Michel Senellart. Translated by Graham Burchell. New York: Picador.

Franke, William. 2017. A Theology of Literature. Eugene: Cascade Books.

Gutiérrez, Gustavo. 1996. Essential Writings. Edited by James B. Nickoloff. London: SCM.

Yu, Hua. 2003. To Live. Translated by Michael Berry. New York: Anchor Books.

Yu, Hua. 2004. Chronicle of a Blood Merchant. Translated by Andrew F. Jones. New York: Anchor Books.

Yang, Huilin. 2014. China, Christianity, and the Question of Culture. Waco: Baylor University Press.

Yang, Huilin. 2010. The Value of Theology in the Humanities: Possible Approaches to Sino-Christian Theology. In Sino-Christian Theology: A Theological Qua Cultural Movement in Contemporary China. Edited by Pan-chui Lai and Jason Lam. Frankfurt: Peter Lang, pp. 101-22.

Jasper, David. 2018. Reflections on the Maturity of Religion and Theology in Literature: A Cultural Dialogue. Christianity and Literature 68: 131-40. [CrossRef]

Sheng, Keyi. 2015. Northern Girls. Translated by Shelly Bryant. Beijing: Penguin Books China, p. 319.

Lai, Pan-chui, and Jason Lam, eds. 2010. Sino-Christian Theology: A Theological Qua Cultural Movement in Contemporary China. Frankfurt: Peter Lang.

Lentricchia, Frank. 1980. After the New Criticism. London: Methuen.

Yan, Lianke. 2007. Serve the People! Translated by Julia Lovell. London: Constable.

Lindbeck, George A. 1984. The Nature of Doctrine: Religion and Theology in a Postliberal Age. London: SPCK.

Liu, Lydia. 1995. Translingual Practice: Literature, National Culture and Translated Modernity—China, 1900-1937. Stanford: Stanford University Press.

Zhang, Longxi. 2015. From Comparison to World Literature. New York: SUNY Press. 
Marion, Jean-Luc. 2002. Being Given: Towards a Phenomenology of Givenness. Translated by Jeffrey L. Kosky. Stanford: Stanford University Press.

McFague, Sallie. 1975. Speaking in Parables. Philadelphia: Fortress Press.

Merton, Thomas. 1999. The Way of Chuang Tzu. Tunbridge Wells: Burns and Oates.

Starr, Chloë, ed. 2008. Reading Christian Scriptures in China. London: T \& T Clark.

Starr, Chloë. 2016. Chinese Theology: Text and Context. New Haven: Yale University Press.

Süskind, Patrick. 1987. Perfume. Translated by John E. Woods. Harmondsworth: Penguin.

Whyte, Bob. 1988. Unfinished Encounter: China and Christianity. London: Fount.

Gao, Xingjian. 2000. Soul Mountain. Translated by Mabel Lee. New York: HarperCollins.

Lu, Xun. 2009. The Real Story of Ah-Q and Other Tales of China: The Complete Fiction of Lu Xun. Translated by Julia Lovell. Harmondsworth: Penguin.

Lu, Xun. 2017. Preface to Outcry. In Jottings under Lamplight. Edited by Eileen J. Cheng and Kirk A. Denton. Cambridge: Harvard University Press.

Yieh, John Y. H. 2008. Reading the Sermon on the Mount in China: A Hermeneutical Enquiry into its History of Reception. In Reading Christian Scriptures in China. Edited by Chloë Starr. London: T \& T Clark.

Geng, Youzhuang. 2016. Between East and West: Word and Image. Waco: Baylor University Press.

Ziolkowski, Eric. 2014. Axial Age Theorizing and the Comparative Study of Religion and Literature. Literature and Theology 28: 129-50. [CrossRef]

(C) 2019 by the author. Licensee MDPI, Basel, Switzerland. This article is an open access article distributed under the terms and conditions of the Creative Commons Attribution (CC BY) license (http://creativecommons.org/licenses/by/4.0/). 